\title{
Overtraining Syndrome
}

\author{
Aşırı Antrenman Sendromu \\ Şensu Dinçer, Aysun Ertuna \\ Sports Medicine Department, Istanbul Faculty of Medicine, Istanbul University, Istanbul, Turkey
}

Ş. Dinçer

0000-0003-1425-2543

A. Ertuna

0000-0001-9931-1324

Geliş Tarihi/Date Received: 19.02.2019

Kabul Tarihi/Date Accepted: 08.05.2019

Yayın Tarihi/Published Online: 05.09.2019

Yazışma Adresi /

Corresponding Author:

Şensu Dinçer

İstanbul Tıp Fakültesi Spor

Hekimliği, İstanbul, Turkey

E-mail: dincersu@gmail.com

(C2020 Türkiye Spor Hekimleri Derneği. Tüm hakları saklıdır.

\begin{abstract}
Demonstrating diagnostic difficulty, overtraining syndrome is a systemic and complex disease. It is characterised by decreased performance, early fatigue, deterioration in sleep patterns and change in social behaviour when training load remains constant or increases. Contextual awareness in both athletes and staff in proximity such as trainers, conditioners, dietitians is amongst the most important factors in preventing and diagnosing the disease as there is no single laboratory parameter or physical examination finding for a definitive diagnosis. Monitoring the variables of the training programme has a critical role in terms of prevention and management. Similarly, data such as muscle pain, sleep quality, stress-causing external factors should be recorded. Improvement requires multi-faceted approach including nutrition, sleep and rest management as well as emotional support.
\end{abstract}

Keywords: Overtraining syndrome, overreaching, staleness, burnout, chronic fatigue

\section{öz}

Aşırı antrenman sendromu (sürantrenman) tanınması oldukça zor, sistemik ve karmaşık bir tablodur. Bu sendrom kendini antrenman yükünün sabit kaldığı veya arttığı durumlarda performansta azalma, çabuk yorulma, uyku düzeninde bozulma, sosyal davranışlarda değişiklikler ile belli eder. Tanınabilmesi ve önlenebilmesindeki en önemli faktör hem sporcunun hem de etrafındaki yardımcı personelin (antrenör, kondisyoner, fizyoterapist, masör vb.) bu konudaki farkındalığıdır. Çünkü kesin tanı için tek bir laboratuvar parametresi veya fiziksel muayene bulgusu yoktur. Antrenman programı ile ilgili değişkenlerin izlenmesi, takip ve önleme açısından kritik öneme sahiptir. Beraberinde kas ağrıları, uyku kalitesi, stres yaratan dışsal faktörler vb. kayıt altına alınmalıdır. İyileşme; beslenme, uyku ve istirahat düzeni, duygusal desteği içeren çok yönlü bir yaklaşım gerektirir.

Anahtar sözcükler: Aşırı antrenman sendromu, aşırı zorlama, bitkinlik, tükenmişlik, kronik yorgunluk

Available at: http://journalofsportsmedicine.org and

http://dx.doi.org/10.5152/tjsm.2020.161

Cite this article as: Dincer S, Ertuna A. Overtraining syndrome. Turk $J$ Sports Med. 2020;55(1):61-8.

\section{GíRiş}

Sporun doğasında yer alan mücadele ve kazanma hırsı sporcuların fiziksel sınırlarını en uç noktaya kadar zorlama eğilimine girmesine neden olmaktadır. Ancak bu zorlanma, uygun süreli istirahat ve toparlanma dönemlerini de içerirse oldukça memnun edici sonuçları da beraberinde getirir. Aksi takdirde bu denge bozulur da sporcu aşırı bir gayret içine girerse aşırı antrenman sendromu (sürantrenman) ile karşı karşıya 
kalınabilir. Bu durum sporcunun kariyerinin son bulması ile noktalanabilir (1). Tanıyı koymak kullanılacak yöntemlerin standardizasyon sinırlılıkları nedeni ile zordur.

\section{Terminoloji}

Literatürde; aşırı antrenman sendromu, aşırı zorlama (overreaching), açlklanamayan performans düşüklüğü sendromu (unexplainedunderperformance syndrome-UUPS), bitkinlik (staleness), tükenmişlik (burnout), kronik yorgunluk sendromu gibi birçok terim zaman zaman bu tablo ile ilgili olarak birbirinin yerine kullanılmaktadır (1).

Aşırı antrenman sendromu: Bu tablo antrenman yükünün sabit kaldığı veya arttığı durumlarda performansta düşüş, çabuk yorulma, uyku düzeninde bozulma, sosyal davranışlarda değişiklikler ile kendini belli eder. Bu durum çok sık ve aşırı antrenman uyaranlarına maruz kalmakla, buna karşın yeterli/uygun dinlenme gerçekleştirememekle ortaya çlkar (2). Amerikan Spor Hekimleri Birliği (ACSM) ve Avrupa Spor Bilimleri Birliği tarafından yayınlanan ortak bildirgede terminolojideki karışıklığa değinilmiş ve "aşırı antrenman sendromu" ismi kullanılmıștır (3).

Overreaching: Kısa-orta süreli aşırı yüklenme durumu olarak tanımlanabilir (4). Ardışık olarak devam eden ağır antrenman ya da karşılaşmaların sportif performansta bir kaç haftalık düşüşe yol açması "overreaching" olarak tanımlanmıştır. Fonksiyonel ve fonksiyonel olmayan iki tipi vardır. Fonksiyonel overreaching yüklenme periyodu sonrası performansta kısa vadeli (2 haftaya kadar) düşüşü ifade eder (5). Ancak fonksiyonel overreaching bir antrenman programının oldukça yararlı bir parçası olabilir. Çünkü planlı overreaching pozitif fizyolojik uyum ve performans gelişimi noktasında kazanç sağlayabilir (1). Fonksiyonel olmayan overreaching ise performansta daha uzun süreli bir düşüşü (yaklaşık 2-4 hafta) tanımlar. Fakat yeterli dinlenme sonrası tam düzelme sağlanır (5). Overreaching tablosundan aşırı antrenman sendromuna geçişte ince bir çizgi bulunmaktadır $(5,6)$.
Açıklanamayan performans düşüklüğü sendromu (Unexplained-underperformance syndrome, UUPS): Antrenman-dinlenme arasindaki dengesizliğin ana neden olarak ortaya konamaması; bunun dişında sosyal, maddi, eğitim gibi parametrelerden de etkilenebilen mültifaktöriyel etiyolojiye sahip olması açısından aşırı antrenman sendromundan farklılık gösterir. Örneğin, önemli bir stres faktörünün veya kötü beslenme gibi nedenlerin de katkıda bulunabileceği vurgulanır. Bu nedenle UUPS tanısı için önkoşul uzun süre dinlenmeye rağmen performansta beklenmeyen bir düşüş olsa da, nedensel açıdan daha geniş bir bakış açısı gerekir (7). Antrenörler de, antrenman yükünün bir göstergesi olan "aşırı antrenman" teriminin bir anlamda kendilerini de sorumluluk altına sokması nedeni ile "açılklanamayan performans düşüklüğü" tanımını kullanmayı tercih edebilmektedir (1).

Bitkinlik (Staleness): Aşırı antrenmanın istenmeyen sonuçlarına atıfta bulunmak için kullanılan bir terimdir. Sporcuların belirlenmiş antrenman rejimine uyum sağlayamamasından kaynaklanır. Yoğun antrenmana karşı gelişen duygusal ve fizyolojik uyumsuz yanitlar olarak tanımlanır.

Tükenmişlik (Burnout): Spora katılıma karşı olumsuz duygusal tepki olarak ifade edilir. Bitkinlik ve tükenmişlik terimleri her ne kadar eş anlamlı olarak kullanılsa da, farklı tıbbi müdahaleler gerektiren ayrı koşullarının olduğu öne sürülmektedir. Aralarındaki önemli farklardan biri de her iki durumda ortaya çıkan duygusal değişikliklerin bitkinlikte antrenman yükü ile, tükenmişlikte ise bilişsel stres faktörleri ile ilişkilendirilmesidir (8).

Kronik Yorgunluk Sendromu: Fiziksel aktivitenin yoğunluğuyla orantısız, altı ay ve daha uzun süre devam eden ve bariz bir nedeni olmayan yorgunluk ile karakterizedir. Kas gücü ve zirve aerobik güçte çok az düşüş olmasına rağmen etkilenen birey yoğun aktiviteden kaçınır. Tetikleyici faktörler olarak; kaygl, depresyon, otonom fonksiyon bozukluğu (sempatik-parasempatik sinir sistemi dengesinin bozulması, postüral hipotansiyon), hormonal dengesizlik, beslenmede 
eksiklikler, bağışıklık sisteminde baskılanma, fiziksel ve duygusal stres, travma, yaralanma, yüksek rakımda egzersiz gösterilmiştir (9).

\section{Epidemiyoloji}

Bilimsel çalışmalarda farklı tanı kriterlerinin kullanılması ve küçük örneklem grupları nedeniyle epidemiyolojik çalışmalar çok net veriler içermemektedir. Ancak genel olarak sporcuların \%5-64 gibi geniş bir aralıkta değișen oranının hayatlarında en az bir kez bu durumu yaşadıkları belirtilmiştir. Cinsiyetler arası farklılıklar açısından ise çalışma sonuçları çelişkilidir. Bilinen noktalar şöyle sıralanabilir (1):

- En fazla riski bisiklet, koşu, yüzme, kürek gibi vücudun uzun süre aşırı stres altında kaldığı dayanıklılık sporları taşımaktadır.

- Beceri düzeyi ile orantılı olarak artmaktadır.

- Önceki aşırı antrenman sendromu öyküsü riski arttırmaktadır.

- Genç kadın sporcularda daha fazla görülmektedir.

\section{Sinıflandırma}

Aşırı antrenman sendromu klinik açıdan sempatik ve parasempatik olarak iki şekilde sınıflandırılmıștır:

Sempatik tip irritabilite (çabuk/kolay sinirlenme), taşikardi, huzursuzluk, ajitasyon (taşkınlık), egzersiz performansında düşüş, aşırı duygusal stres, tansiyonda artış ile karakterizedir. Parasempatik tip irritabilitede ise; egzersiz ve toparlanma sirasinda kronik yorgunluk hali, performansta düşüş, uyku düzeninde bozulma, sık tekrarlayan enfeksiyonlar, kaygı, depresyon, sinirlilik, genel yorgunluk ve antrenman için isteksizlik, bağışıklık sisteminde ve üreme sisteminde bozukluk gibi durumlar yer alır (10).

\section{Patofizyolojide Yer Alan Teoriler}

Sitokin teorisi: Bu teoriye göre yüksek şiddetli ve kapsamlı antrenmanlar arasinda dinlenme süresinin yetersizliği kaslarda ve eklemlerde doku hasarlanmasına neden olurken, başlangıçta lokal enflamasyona, izleyen dönemde ise sistemik enflamasyona yol açabilmektedir.
İnterlökin 1- $\beta$, Tümör nekrozis faktör- $\alpha$ ve İnterlökin-6 gibi proenflamatuvar sitokinlerin salınımı artar ve bu sitokinlerin uzun süreli yüksekliği merkezi ve periferik yorgunluğa neden olurken, hormonal ve metabolik değișikliklere de yol açar $(1,11)$.

Otonom dengesizlik teorisi: $\mathrm{Bu}$ teoriye göre başlangıç mekanizması, ağır antrenman sırasında salınan fazla miktardaki katekolaminin zamanla negatif geri bildirim yoluyla bazal katekolamin seviyesinde düşüşe neden olmasıdır. İkinci olarak, egzersizle birlikte artış gösteren metabolik süreç, plazma amino asit seviyelerinde dengesizlik ve bazı aminoasitlerin (fenilalanin, triptofan, tirozin) konsantrasyonunda artışa yol açan beyin nörotransmitter metabolizması değişimlerine neden olur. Beyindeki triptofan ve serebral dopamin derişimindeki artış sempatik sinir sistemi üzerinde inhibitör etki gösterir. Bunlara ek olarak yüksek yoğunluklu egzersizin ortaya çıkardığı merkezi sıcaklık artıșı da hipotalamustaki sempatik sinir sistemi merkezlerinde baskılayıcı etki gösterebilir. Son olarak, egzersize katılan kaslardaki katekolamin reseptörü aşağı regülasyonuna bağlı olarak negatif geri bildirim ortaya çıkar.

Glikojen teorisi: Ardışık yüklemeler sonrasında ortaya çıkan kas hasarının GLUT-4 proteininin hücre membranına sunumunu olumsuz etkileyebilmesinin glikoz taşınmasını azaltıcı etki gösterebileceği ve hücre içi glikojen içeriğinin azalmasına yol açabileceği düşünülmektedir. Orta ve yüksek yoğunluklu egzersizde birincil enerji kaynağı olan glikojen periferik yorgunluğa ve performansta düşüşe neden olur.

Merkezi yorgunluk teorisi: Azalmış glikojen sentezi, enerji açığını azaltmak için dallı zincirli aminoasitlerin (BCAA) glikoza oksidasyonunun artmasına neden olur. Eş zamanlı biçimde ikincil enerji kaynağı olarak yağ asidi seviyesinde artış olur. Yağ asitleri triptofanla albümine bağlanmak için yarışa girer ve plazma triptofan seviyesi artar. Triptofan ve BCAA kan beyin bariyerini geçmek için aynı taşıyıcıyı kullandıklarından, plazma BCAA seviyesindeki düşüş ve triptofandaki artış merkezi sinir sistemine taşınan triptofan seviyesini artırır. Triptofan burada serotoni- 
ne (5-HT) dönüşür. Bu da aşırı antrenman sendromunda görülen birçok nöroendokrin ve duygusal tablo ile ilişkilendirilir $(1,11,12)$.

\section{TANI/AYIRICI TANI}

Aşırı antrenman sendromu aslında bir dışlama tanısıdır. Bir sporcu yorgunluk, ruh hali değișimi, sık yaralanmalarla ve artmış kas ağrıları ile birlikte performansının azalmasından yakınıyorsa aşırı antrenman sendromu tanısı konulmadan önce ayırıcı tanıda öncelikle; majör depresyon, bağımlılık, anemi, enfeksiyöz mononükleoz, hipotiroidi, diabetes mellitus, adrenal hastalıklar, yeme bozukluğu ve hepatit gibi hastalıklar akla gelmeli ve ekarte edilmelidir. Așırı antrenman sendromu birçok klinik ve endokrinolojik hastalığı taklit ettiği için tanısı zor konulan bir durumdur (1).

\section{Tanı Basamakları}

Anamnez: Temel yakınma iyi sorgulanmalıdır. Yeterli dinlenmeye rağmen performansta düşüş olup olmadığı, ruh hali değişiklikleri, performans düşüklüğüne neden olabilecek diğer nedenler, kronik hastalık veya var olan hastalık öyküsü, sporcunun branşındaki hedefi, yaklaşan bir yarışma için antrenman programında artış olup olmadığı, beslenme tarzı, kullanılan ilaçlar (lipit düşürücüler, oral kontraseptif kullanımı, insülin, diüretik, antihipertansif ajanlar, betaagonistler, alkol, antidepresan, antihistaminik, anksiyolitik, beta-bloker) sorgulanmalıdır (13).

Fiziksel muayene: Genellikle normaldir. Ancak kan basıncında ve kalp atım hızında yükselme saptanabilir.

Laboratuvar: İlk etapta ucuz ve kolay ulaşılabilir parametreler bakılmalıdır. Kalori dengesinin saptanmasi, monospot testi (enfeksiyöz mononükleoz için), kan biyokimyası, elektrokardiyografi öncelikle yapılmaldır.

Aşırı antrenman sendromu tanısında kullanılan kolay ölçülebilir, minimal invazif, uygun maliyetli, antrenman süreci ile de seviyesi etkilenmeyen tanısal biyolojik bir belirteç yoktur. $\mathrm{Bu}$ alanda yapılan çalışmaların sonuçları oldukça çelişkilidir. Literatürde karşımıza çıkan belirteçler şu şekilde sıralanabilir:
Kreatin kinaz (CK): Așırı antrenman sendromuna spesifik değildir. Çünkü dolaşımdaki CK düzeyi düşük ve orta dereceli antrenmanlar, eksantrik egzersiz veya alışkın olunmayan antrenman sonrasında da artar $(5,14)$. Orta yoğunluklu egzersiz sonrası CK düzeyi için üzerinde uzlaşılmış bir "normal" değer bulunmamaktadır. Ancak çalışmalarda sedanter bireyler ve sporcular için belirlenmiş bazı referans değerlere rastlanmaktadır. Bir çalışmada erkek sporcular için üst referans değer 1083 U.L-1 kadın sporcular için 513 U.L -1 $^{1}$ olarak belirtilmiştir. Ancak burada da spor türüne göre referans değerlerinin değişkenlik gösterdiğine dikkat çekilmiştir. Örneğin yüzücülerdeki ortalama CK değeri 523 U.L-1 iken, futbolcularda bu değerin 1492 U.L-1 düzeyinde olduğu belirtilmiştir. Aynı çalışmada sporcu olmayan bireyler için belirlenen referans değerler erkekler için 491 U.L-1 , kadınlar için 252 U.L-1'dir. Ancak sporcu olmayan bireylerde erkekler için üst sınırı 350 U.L $^{-1}$, kadınlar için 200 U.L-1 olarak belirten yayınlar da vardır (15-17). Buradan da anlaşlacağı üzere, CK değeri için standart bir değer bulunmamaktadır. Ancak her sporcunun CK değerlerinin bireysel bazda izlenerek önemli sapmaların aşırı antrenman sendromunun klinik belirtileri ile birlikte ele alındığında yol gösterici olabileceği söylenebilir (18).

Kalp hızı(HR): İstirahatte, antrenman öncesi ve sonrasinda izlenmelidir.

Kalp hızı değişkenliği (Heart-rate variability$H R V$ ): Kardiyak otonom dengenin göstergesidir. Ardışık iki kalp atışı arasındaki kalp hızı değişimini tanımlar. Otonom sinir sistemi sempatik ve parasempatik düzenleme yoluyla kardiyovasküler fonksiyonu kontrol eder (19). Egzersiz sırasında ve egzersizden sonra homeostazı sürdürmek için çalışır (20). HRV'deki akut düşüşlerin yoğun dayanıklılık antrenmanı, direnç antrenmanı, kombine antrenman, spora özgü antrenman ve yarışmadan sonra ortaya çıktığı bildirilmiştir (21-25). Bunlar dikkate alındığında düşük HRV'nin antrenman ve yarışmadan kaynaklanan akut yorgunluğun refleksi olduğu düşünülmektedir. Bellenger ve ark. sistematik derlemelerinde atletik performans iyileşmelerinin dinlenme HRV ölçümlerindeki eş zamanlı 
artışlarla ilişkili olduğunu belirtmiş ve bu dönemde gözlemlenen artışların antrenmana adaptasyonu kolaylaştırdığını ve parasempatik kalp hızı düzenlenmesi ile ilişkili olduğunu öne sürmüşlerdir (26). Genel olarak HRV'deki artış, yararlı bir antrenman adaptasyonunu ve daha iyi bir toparlanma durumunu yansitirken, HRV'deki düşüş ise stresli ve daha kötü bir toparlanma durumunu yansitır. Genetik, cinsiyet, vücut ağırlığı, etnik köken ve yaş gibi faktörler farklı HRV yanıtlarına neden olabilir. HRV ölçümü için geliştirilmiş bazı mobil uygulamalar olsa da, ölçüm sırasında sporcunun pozisyonu ve ölçüm süresi gibi parametrelerde farklılıklar nedeni ile güvenilirlikleri ortaya konamamıştır (27-29). Sonuç olarak HRV'nin, sporcunun iyileşmesini veya fizyolojik adaptasyon durumunu belirlemek için diğer toplanan endekslerle bütüncül bir șekilde kullanıldığında daha etkili bir sonuç verebileceği söylenebilir.

Kan laktat düzeyi: Maksimal düzeyde yapılan egzersize karşı üretilen laktat miktarı aşırı antrenman sendromunda sporcunun normal değerlerine göre daha düşüktür. Ayrıca kan laktat düzeyi, kas ve karaciğerdeki glikojen düzeyi ile ters orantılıdır ve sadece aşırı antrenman sendromu nedeni ile değil, sporcunun kondisyon düzeyi ile de değişkenlik gösterir. Bununla birlikte "overreaching" tablosundan ayrımı sağlamaz (1).

Tükürükte IgA düzeyi: Son yıllarda üzerinde sıç̧a durulan bir diğer parametre olarak karşımıza çıkmaktadır. Mukozal bağışıklık sisteminin önemli bir savunma elemanı olan IgA'nın aşırı antrenman sendromlu sporcularda iyi antrene sporculara göre azaldığı gösterilmiştir (30). Tükürük IgA düzeyinin bireyler arası geniş farklılıklar göstermesi nedeni ile sporcunun bireysel tükürük IgA profilinin çıkartılıp bu değerlerdeki farklılıkların kıyaslanması önerilmektedir (31).

Hormonal değerlendirme: Cadegiani ve ark. fonksiyonel/fonksiyonel olmayan overreaching ve aşırı antrenman sendromunda tanısal amaçlı kullanılabilecek hormonları araștırmışlardır (32). Buna göre bazal hormon değerleri ile fonksiyonel/fonksiyonel olmayan overreaching ve aşırı antrenman sendromu arasında bir ilişkinin varlığından söz edilemese de adrenokortikotropik hormon (ACTH) ve büyüme hormonunun (GH) maksimal egzersiz ile oluşturulan stimülasyon testlerine akut yanıtının baskılandığı, bu nedenle de iyi birer belirteç olabilecekleri öne sürülmüştür. Ancak burada dikkat çeken kısıtlayıcı faktörlerden biri, maksimal egzersiz stimülasyon testlerinin endokrinoloji otoriteleri arasında geniş kabul gören, yaygın olarak kullanılan testler olmamasidır.

Duygu durum değerlendirme: Klinik değerlendirmenin bir tarafı da duygu durum değerlendirmesidir. Bunun için duygu durum profili anketi (POMS) kullanılabilir (33). POMS kısa süreli duygu durum değişikliklerini değerlendirmek için geliştirilmiş olup Türkçe versiyonu 58 madde ve altı alt ölçekten (gerginlik, öfke, yorgunluk, çökkünlük, dinçlik, şaşkınlık) oluşmaktadır (34). Aşırı antrenman sendromunun erken tanınmasında kullanışlı bir yöntem olmakla birlikte, nedeni hakkında bilgi vermez. Bundan başka sporda stres ve toparlanma anketi (RESTQ-Sport/Recovery and Stress Questionnaire in Sport) de kullanılabilir (35). Bu anket antrenman yoğunluğu ile ilișkili ruh halini daha özgün olarak sorgulayan bir ankettir. Ancak tek başına tanı koydurmaz. Ek olarak toparlanmanın beslenme, hidrasyon, uyku ve dinlenme, gevşeme, duygusal stres, esnetme/soğuma alt başlıkları ile değerlendirildiği toplam toparlanma kalitesi (TQR/total quality recovery) skoru da başka bir değerlendirme anketi olarak kullanılabilir (36).

Sonuç olarak, aşırı antrenman sendromunun klinik olarak tanınması ve kesin tanısının konulması zor olduğundan, ortaya çıkmadan önce önlenmesi için atılacak adımlar daha değerli olacaktır. $\mathrm{Bu}$ nedenle sporcuların hem klinik hem de laboratuvar verilerinin düzenli izlenmesi ve bu verilerin kayıt altına alınması oldukça önemlidir. Yani sporcu izlemi ve aşırı antrenman sendromunu önleme stratejileri iç içe yürütülmelidir.

\section{Sporcu İzlemi-Önleme Yaklaşımı}

Aşırı antrenman sendromu, her ne kadar bütün sporcular için önemli bir tablo olsa da, risk gruplarının bilinmesi önleyici yaklaşımlar 
açısından önemlidir. Risk grupları şöyle sıralanabilir:

- Bir spor dalına yeni başlayanlar aşırı istekli olabilirler ve antrenman-dinlenme dengesini bozabilirler.

- İlk başarılarını kazanan sporcular bu motivasyonla daha sıkı antrenman yapmaya başlarlar.

- Kendilerinden daha başarılı sporcularla antrenman yapanlar.

- Herhangi bir antrenman ekibi ya da antrenörü olmayan, daha çok tek başına çalışan sporcular.

- Deneyimli ve bilinçli bir antrenörle çalışmak maksimum performans için olduğu kadar aşırı antrenman sendromundan kaçınmak için de önemlidir.

Antrenman programı ile ilgili değişkenler de izlem ve önleme açısından kritiktir. Örneğin antrenman ve dinlenme miktarının dengeli bir şekilde ayarlanması, sporcunun etrafındaki kimselerin, özellikle de antrenörlerin bu konudaki farkındalıkları ve eğitimleri oldukça önemlidir. Antrenman periyodizasyonu, program içinde yeterli toparlanma süresinin yer alması ile ilgili uygun düzenlemeler mutlaka yapılmalıdır. Toparlanma sporun en önemli bölümlerindendir. Antrenman veya yarışma sonrası en ideal toparlanma için:

- Hidrasyon ve beslenme

- Uyku ve dinlenme

- Gevşeme ve duygusal destek

- Esnetme ve aktif dinlenme anahtar noktalardir (36).

Masaj, hidroterapi gibi rahatlama tekniklerinin yanı sıra, daha fazla sıvı ve karbonhidrat takviyesi gibi yöntemler daha yüksek miktardaki antrenman düzeyleri ile baş etmede yararlıdır (5). Sporcu izlemi sırasında gerekirse sporcuya üç günlük beslenme günlüğü tutturulmalı ve eksik noktalar varsa beslenme uzmanına yönlendirilmelidir. Sporcuların bu farkındalığa sahip olması ve izleyen sağlık ekibi ve teknik ekibin de bu parametrelerin yerine getirilip getirilmediği konusunda dikkatli olması gerekir.

İzlem: Așırı antrenman sendromu tanısını koymakta tek başına belirleyici bir yöntem olmadığından, laboratuvar ve klinik parametreleri birlikte izlenmelidir. Böylece sporcuda aşırı antrenman sendromu tablosu tam oturmadan tanınabilir, bazı önlemler alınmasına olanak sağlanabilir. Bunun için aşağıda sıralanan bazı değerler periyodik olarak kaydedilmelidir (30):

- Antrenman detayları (süre, yoğunluk, şiddet, algılanan zorluk derecesi, kalp atım hızı yanitı)

- Sporcunun antrenman programı hakkındaki düşüncesi

- Sporcunun çeşitli anketler ile iyilik hali derecelendirmesi (aylık anket uygulamaları)

- Uyku kalitesi

- Kas ağrıları

- İrritabilite

- Stres yaratan ev, iş faktörleri, yaralanma, hastalık gibi durumlar

\section{TEDAVİ}

Dinlenme: Aşırı antrenman sendromunun tanısı karmaşık olduğu için tek bir kesin tedavi yöntemi de yoktur. Her vakanın kendi kliniğinden yola çıkılarak tedavi planlaması yapılmalıdır. Ancak tedavinin ortak ve en önemli bileşeni, semptomların şiddetine göre değişmekle birlikte mutlak veya göreceli istirahattir. Hafif olgular sadece birkaç haftalık göreceli dinlenme sonrası iyileşebilirken, daha ciddi olgular aylar süren göreceli veya tam istirahati gerektirebilir veya iyileşmeyebilir (5).

Beslenme: Beslenme düzeni, sıvı-elektrolit alımı konusunda eksiklerin saptanması ve varsa negatif enerji dengesinin düzeltilmesi gerekir.

Glutamin takviyesi: Kanıt düzeyi düşük olmakla birlikte bağışıklık sisteminin glutamin ilişkisi nedeni ile önerilebilir $(30,37)$. Glutamin bağışıklık sisteminin bazı hücreleri için önemli bir yakıttır. Travma, açlık veya uzun süreli/yorucu egzersiz gibi stres durumlarında, kan- 
daki glutamin derişimi genellikle önemli ölçüde azalır. Dayanıklılık sporcularında bu düşüş, bağışıklık sisteminin geçici olarak baskılanması ile eş zamanlı meydana gelir. Glutamin ve glutamin öncüllerinin dayanıklılık sporcularında hastalık insidansını azalttığı gösterilmiştir (38).

Yukarıda bahsedilenlere ek olarak yakın zamanda yapılan bir olgu çalışmasında, aşırı antrenman sendromunda redoks belirteçlerinde (plazma antioksidan kapasitesi, hidroperoksit, süperoksit dismutaz, koenzim Q-10, vitamin E, karotenoidler vb.) ortaya çıkan farklılıkların sonucu olarak vücut redoks dengesinin değiştiği ortaya konmuştur. Bu doğrultuda da beslenme programının redoks sistemini dengeleyici ve antioksidan nitelikte olan karotenoid ve antosiyanin içerikli fitobesinlerle takviye edilmesi önerilmiştir (39).

İlaç tedavisi: Selektif serotonin geri alım inhibitörleri ve serotonin-norepinefrin geri alım inhibitörleri grubu psikiyatrik ilaçların hem toparlanma süresini azalttığı, hem de psikolojik semptomları iyileștirdiği öne sürülmektedir (1).

Oksijen uygulaması: Tekrarlı, aralıklı hipoksihiperoksi uygulaması ile birlikte hafif, çoğunlukla spora özgü egzersiz programı önerilmektedir (40). Buna göre düşük yoğunluklu egzersizle birlikte dört haftalık tekrarlı hipoksi-hiperoksi uygulamasının aşırı antrenman sendromu tanısı konulmuş sporcularda fiziksel kapasiteyi, otonom sinir sistemi yanıtını ve hipoksiye toleransı geliștirdiği gösterilmiştir.

\section{SONUÇ}

Aşırı antrenman sendromu, tanınması oldukça zor, sistemik ve karmaşık bir tablodur. Tanınması ve önlenebilmesindeki en önemli faktör, hem sporcunun hem de etrafındaki yardımcı personelin bu konudaki farkındalığıdır. Performans düşüklüğü mutlaka yakından izlenmeli ve iyileşme için beslenme, uyku ve istirahat düzeni ile duygusal desteği içeren çok yönlü bir yaklaşım sergilenmelidir.

\section{KAYNAKLAR}

1. Carfagno DG, Hendrix JC 3rd. Overtraining syndrome in the athlete: current clinical practice. Curr Sports Med Rep. 2014;13(1):45-51.
2. Kreher JB. Diagnosis and prevention of overtraining syndrome: an opinion on education strategies. Open Access J Sports Med. 2016;7:115.

3. Meeusen R, Duclos M, Foster C, et al. Prevention, diagnosis, and treatment of the overtraining syndrome: joint consensus statement of the European College of Sport Science and the American College of Sports Medicine. Med Sci Sports Exerc. 2013;45(1):186-205.

4. Hooper SL, Mackinnon LT, Howard A, et al. Markers for monitoring overtraining and recovery. Med Sci Sports Exerc. 1995;27(1):106-12.

5. Halson S. Overtraining syndrome in athletes. In: O'Connor FG, Grayzel J, Eds. UpToDate. Retrieved 2017 from https://www.uptodate.com/contents/overtrainingsyndrome-in-athletes.

6. Vrijkotte S, Roelands B, Pattyn N, et al. The overtraining syndrome in soldiers: insights from the sports domain. Mil Med. 2019;184(5-6):e192-200.

7. Lewis NA, Collins D, Pedlar CR, et al. Can clinicians and scientists explain and prevent unexplained underperformance syndrome in elite athletes: an interdisciplinary perspective and 2016 update. BMJ Open Sport Exerc Med. 2015;1(1):e000063.

8. Hanin YL. Emotions in sport: current issues and perspectives. In: Handbook of Sport Psychology. Tenenbaum G, Eklund RC, Eds., 3rd ed. Hoboken, NJ: John Wiley \& Sons. p. 31-58; 2012.

9. Shephard RJ. Chronic fatigue syndrome: an update. Sports Med. 2001;31(3):167-94.

10. Günay M, Cicioğlu İ. Sürantrenman ve sporcu performansı. Gazi Beden Eğitimi ve Spor Bilimleri Dergisi. 1998;3(1):11-6.

11. Smith LL. Cytokine hypothesis of overtraining: a physiological adaptation to excessive stress? Med Sci Sports Exerc. 2000;32(2):317-31.

12. Mittleman KD, Ricci MR, Bailey SP. Branched-chain amino acids prolong exercise during heat stress in men and women. Med Sci Sports Exerc. 1998;30(1):83-91.

13. Hawley CJ, Schoene RB, Harmon KG, et al. Overtraining syndrome: a guide to diagnosis, treatment, and prevention. Phys Sportsmed 2003;31(6):25-31.

14. Baird MF, Graham SM, Baker JS, et al. Creatinekinase- and exercise-related muscle damage implications for muscle performance and recovery. $J$ Nutr Metab. 2012;960363.

15. Wu AHB, ed. Tietz Clinical Guide to Laboratory Tests. St Louis, Missouri, USA; WB Saunders Co. p. 306-9; 2006.

16. Wong ET, Cobb C, Umehara MK, et al. Heterogeneity of serum creatine kinase activity among racial and 
gender groups of the population. Am J Clin Pathol. 1983;79(5):582-6.

17. Schumann G, Klauke R. New IFCC reference procedures for the determination of catalytic activity concentrations of five enzymes in serum: preliminary upper reference limits obtained in hospitalized subjects. Clin Chim Acta. 2003;327(12):69-79.

18. Mougios V. Reference intervals for serum creatine kinase in athletes. Br J Sports Med. 2007;41(10): 674-8.

19. Robinson BF, Epstein SE, Beiser GD, et al. Control of heart rate by the autonomic nervous system. Studies in man on the interrelation between baroreceptor mechanisms and exercise. Circ Res. 1966;19(2):40011.

20. Aubert AE, Seps B, Beckers F. Heart rate variability in athletes. Sport Med. 2003;33(12):889-919.

21. Plews DJ, Laursen PB, Kilding AE, et al. Heart-rate variability and training-intensity distribution in elite rowers. Int $J$ Sports Physiol Perform. 2014;9(6):1026-32.

22. Chen JL, Yeh DP, Lee JP, et al. Parasympathetic nervous activity mirrors recovery status in weightlifting performance after training. J Strength Cond Res. 2011;25(6):1546-52.

23. Williams $\mathrm{S}$, Booton $\mathrm{T}$, Watson $\mathrm{M}$, et al. Heart rate variability is a moderating factor in the workloadinjury relationship of competitive crossfit ${ }^{\mathrm{TM}}$ athletes. J Sports Sci Med. 2017;16(4):443-9.

24. Flatt AA, Esco MR, Allen JR, et al. Heart rate variability and training load among NCAA division-1 college football players throughout spring camp. J Strength Cond Res. 2018;32(11):3127-34.

25. Edmonds RC, Sinclair WH, Leicht AS. The effect of weekly training and a game on heart rate variability in elite youth Rugby League players. Int J Sports Med. 2013;34(12):1087-92.

26. Bellenger CR, Fuller JT, Thomson RL, et al. Monitoring athletic training status through autonomic heart rate regulation: a systematic review and meta-analysis. Sport Med. 2016;46(10):1461-86.

27. Perrotta AS, Jeklin AT, Hives BA, et al. Validity of the elite HRV smartphone application for examining heart rate variability in a field-based setting. $J$ Strength Cond Res. 2017;31(8):2296-302.
28. Makivić B, Nikić MD, Willis MS. Heart rate variability (HRV) as a tool for diagnostic and monitoring performance in sport and physical activities. J Exerc Physiol Online. 2013;16(3):103-31.

29. Pichot V, Roche F, Gaspoz JM, et al. Relation between heart rate variability and training load in middledistance runners. Med Sci Sports Exerc. 2000;32(10):1729-36.

30. Brukner P, Khan K. Brukner \& Khan's Clinical Sports Medicine. North Ryde, NSW: McGraw-Hill; 2012.

31. Gleeson M. Biomechanical and immunological markers of over-training. J Sports Sci Med. 2002;1(2): 31-41.

32. Cadegiani FA, Kater CE. Hormonal aspects of overtraining syndrome: a systematic review. BMC Sports Sci Med Rehabil. 2017;9:14.

33. McNair DM, Lorr M, Droppleman LF. Edits Manual for the Profile of Mood States. Rev. ed., San Diago, California: Edits/Educational and Industrial Testing Service;1992.

34. Selvi Y, Gulec M, Aydin A, et al. Psychometric evaluation of the Turkish language version of the profile of mood states (POMS). J Mood Disord. 2011;1(4):152-61.

35. Kellmann M, Kallus KW. Recovery-Stress Questionnaire for Athletes: User Manual (Vol1): Champaign, IL: Human Kinetics; p. 5-11, 2001.

36. Kenttä G, Hassmén P. Overtraining and recovery. A conceptual model. Sport Med. 1998;26(1):1-16.

37. Hiscock N, Mackinnon LT. A comparison of plasma glutamine concentration in athletes from different sports. Med Sci Sports Exerc. 1998;30(12):1693-6.

38. Bassit RA, Sawada LA, Bacurau RF, et al. The effect of BCAA supplementation upon the immune response of triathletes. Med Sci Sports Exerc. 2000;32(7):1214-9.

39. Lewis NA, Redgrave A, Homer M, et al. Alterations in redox homeostasis during recovery from unexplained underperformance syndrome in an elite international rower. Int $J$ Sports Physiol Perform. 2018;13(1):107-11.

40. Susta D, Dudnik E, Glazachev OS. A programme based on repeated hypoxia-hyperoxia exposure and light exercise enhances performance in athletes with overtraining syndrome: a pilot study. Clin Physiol Funct Imaging. 2017;37(3):276-81. 